\title{
Fluorescently labeled ribosomes as a tool for analyzing antibiotic binding
}

\author{
BEATRIZ LLANO-SOTELO ${ }^{1}$, ROBYN P. HICKERSON ${ }^{2,3,4}$, LAURA LANCASTER ${ }^{2,3}$, HARRY F. NOLLER ${ }^{2,3}$, \\ and ALEXANDER S. MANKIN ${ }^{1}$ \\ ${ }^{1}$ Center for Pharmaceutical Biotechnology, University of Illinois, Chicago, Illinois 60607, USA \\ ${ }^{2}$ Department of Molecular, Cell and Developmental Biology, University of California at Santa Cruz, Santa Cruz, California 95064, USA \\ ${ }^{3}$ Center for Molecular Biology of RNA, University of California at Santa Cruz, Santa Cruz, California 95064, USA
}

\begin{abstract}
Measuring the binding of antibiotics and other small-molecular-weight ligands to the 2.5 MDa ribosome often presents formidable challenges. Here, we describe a general method for studying binding of ligands to ribosomes that carry a site-specific fluorescent label covalently attached to one of the ribosomal proteins. As a proof of principle, an environment-sensitive fluorescent group was placed at several specific sites within the ribosomal protein S12. Small ribosomal subunits were reconstituted from native $16 \mathrm{~S}$ rRNA, individually purified small subunit proteins, and fluorescently labeled S12. The fluorescence characteristics of the reconstituted subunits were affected by several antibiotics, including streptomycin and neomycin, which bind in the vicinity of protein S12. The equilibrium dissociation constants of the drugs obtained using a conventional fluorometer were in good agreement with those observed using previously published methods and with measurements based on the use of radiolabeled streptomycin. The newly developed method is rapid and sensitive, and can be used for determining thermodynamic and kinetic binding characteristics of antibiotics and other small ribosomal ligands. The method can readily be adapted for use in high-throughput screening assays.
\end{abstract}

Keywords: ribosome; antibiotics; fluorescence; streptomycin; $30 \mathrm{~S}$ subunit

\section{INTRODUCTION}

The ribosome plays a central role in gene expression. It is composed of two subunits: large and small (30S and $50 \mathrm{~S}$ in bacteria). Each subunit is assembled from one or several rRNA molecules and $\sim 20-30$ ribosomal proteins. The molecular weight of the ribosome $(2.5 \mathrm{MDa}$ in bacteria) and its size ( $\sim 20 \mathrm{~nm}$ in diameter) far exceed the weight and size of an average enzyme and make the ribosome one of the largest and most complex enzymes in the cell. Functional and structural studies have revealed that the ribosome is essentially an RNA machine (for review, see Green and Noller 1997; Moore and Steitz 2003; Ogle et al. 2003). The large rRNA molecules (the 1500-nucleotide [nt]-long 16S rRNA and 2900-nt-long 23S rRNA in bacteria) form the core structural scaffold of the $30 \mathrm{~S}$ and $50 \mathrm{~S}$ subunits, respectively (Ban et al. 2000; Carter et al. 2000; Schluenzen

\footnotetext{
${ }^{4}$ Present address: TransDerm, Inc., Santa Cruz, CA 95060, USA.

Reprint requests to: Alexander S. Mankin, Center for Pharmaceutical Biotechnology, University of Illinois, m/c 870, $900 \mathrm{~S}$. Ashland Avenue, Chicago, IL 60607, USA; e-mail: shura@uic.edu; fax: (312) 413-9303.

Article published online ahead of print. Article and publication date are at http://www.rnajournal.org/cgi/doi/10.1261/rna.1681609.
}

et al. 2000; Yusupov et al. 2001). The major functional centers of the ribosome, such as the decoding center in the small subunit and the peptidyl-transferase center in the large subunit, are built primarily from RNA. However, the ribosomal proteins also play important roles in the structure and function of the ribosome. In spite of the mainly peripheral locations of most ribosomal proteins, their extended appendages reach deep into the core of the ribosome and often approach important functional centers (Maguire et al. 2005; Lee et al. 2007).

The importance of protein synthesis, as well as the RNA nature of the ribosome, make it an excellent antibiotic target. A variety of natural antibiotics inhibit cell growth by binding to the ribosome and blocking protein synthesis. Many of these compounds have become prototypes of drugs that are widely used for treatment of bacterial infections. The majority of protein synthesis inhibitors act at well-recognized functional centers of the ribosome such as the decoding center, the peptidyl-transferase center, the exit tunnel, and others (Brodersen et al. 2000; Yonath 2005; Schuwirth et al. 2006; Borovinskaya et al. 2007; Böttger 2007; Wilson et al. 2008). 
In spite of the early success of antibiotics in curing infectious diseases, the spread of resistant strains has diminished the usefulness of these "old" drugs. The emergence of drugresistant pathogens has prompted the search for new antibacterials, including those with unique mechanisms of action, e.g., those that target unexploited binding sites within the ribosome (Wenzel and Edmond 2000; Belova et al. 2001; Yassin et al. 2005; Yonath 2005; Yassin and Mankin 2007; Brandi et al. 2008a,b). One of the critical steps in development of new protein synthesis inhibitors is characterizing the interactions of potential antibiotics with the ribosome. Defining which of the ribosomal subunits is targeted by the compound, identifying the site of drug action, and measuring the thermodynamic and kinetic parameters of antibiotic binding are important prerequisites for successful advancement of a medically sound antibiotic.

This task is complicated by the size and complexity of the ribosome and the difficulty in analyzing interactions between reactants that differ in size by more than three orders of magnitude. The most commonly used approaches for studying the binding of drugs to the ribosome are equilibrium dialysis (Schreiner and Nierhaus 1973; Böck et al. 1979; Grise-Miron and Brakier-Gingras 1982), gel filtration (McNicholas et al. 2000), and filter binding, which often rely on the use of radioactively labeled compounds and are rarely available. Several attempts have been made to use fluorescent derivatives of antibiotics (Hall et al. 1977; Brandt-Rauf et al. 1978; Yan et al. 2005). However, attaching a bulky fluorescent group to a small drug molecule may dramatically change its biochemical characteristics and produce skewed results. Other important methods, such as footprinting or cross-linking, are laborious and time consuming (Tejedor and Ballesta 1985; Tejedor et al. 1985; Moazed and Noller 1987; Leach et al. 2007). These traditional methodologies are not readily amenable to highthroughput screening applications and do not provide real-time binding information, creating a need for novel methodologies.

We describe here a new method for studying the interaction of putative antibiotics and other ligands within the ribosome based on site-specific incorporation of a fluorescent label on the ribosome in the vicinity of the putative drug-binding site. In the current approach, the fluorophore is introduced by incorporation of a fluorescently la- beled ribosomal protein through in vitro reconstitution of a ribosomal subunit. Binding of a ligand to the ribosome changes the microenvironment of the fluorophore, resulting in changes of its fluorescence. The method is sensitive and rapid, and has the potential to be used for measurement of the thermodynamic and kinetic binding properties of ribosomal ligands, and is readily adaptable to highthroughput screening methods.

\section{RESULTS}

In order to validate the utility of fluorescently labeled ribosomes for analysis of antibiotic binding, we analyzed the interaction of the well-studied antibiotic streptomycin with fluorescently modified small ribosomal subunits. Streptomycin binds to the $30 \mathrm{~S}$ subunit at the junction of the shoulder and platform domains (Fig. 1A,B; Moazed and Noller 1987; Carter et al. 2000). At its site of action, streptomycin contacts nucleotide residues located in helices h18, h27, h28, and h44 of $16 \mathrm{~S}$ rRNA. The arrangement of rRNA elements in this site of the ribosome is stabilized, in part, by protein S12, which is also directly involved in interaction with streptomycin (Schluenzen et al. 2000; Wimberly et al. 2000). Specifically, Lys $_{45}$ of S12, which is
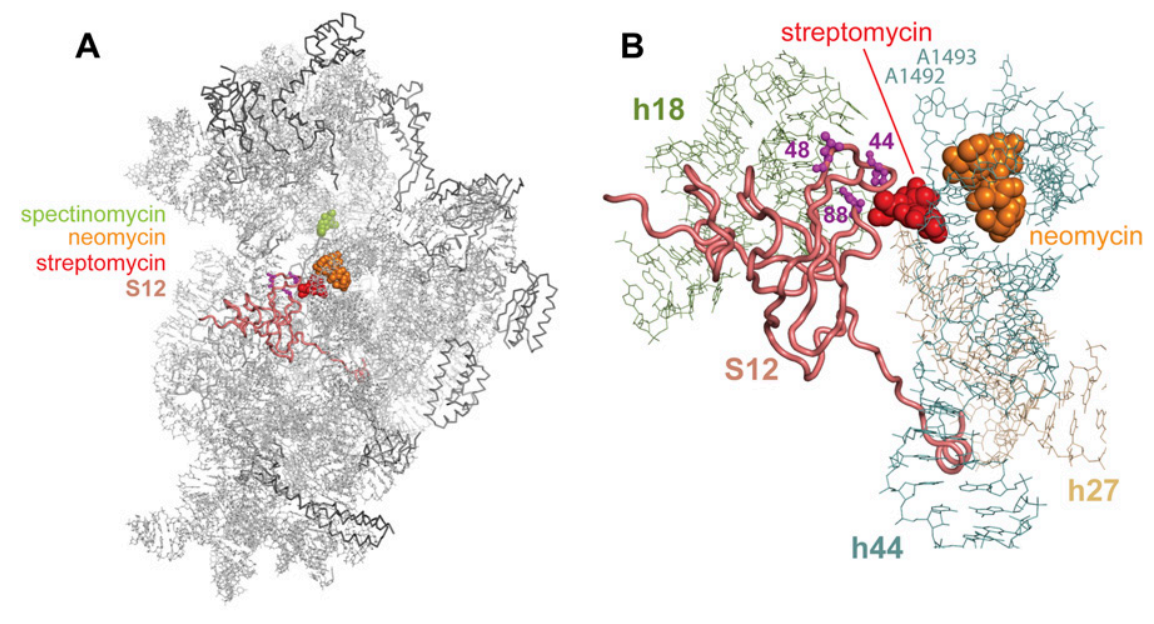

\section{C}

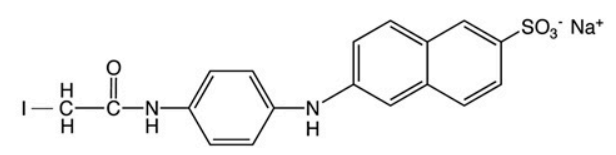

FIGURE 1. (A) Binding sites of streptomycin (red), neomycin (orange), and spectinomycin (green) in the small ribosomal subunit. The shown structure represents the E. coli small ribosomal subunit (PDB accession number 2QAL) (Borovinskaya et al. 2007), with 16S rRNA shown as light gray and proteins (ribbon representation) as dark gray. The $\mathrm{C} \alpha$-chain of protein S12 is shown as a tube and colored pink. (B) Close-up view of the relative locations of streptomycin, neomycin, and protein S12 in the small ribosomal subunit. 16S rRNA elements (helices 18, 27, and 44) are shown as stick representations. The adenosine residues A1492 and A1493 that undergo a dramatic conformational change upon neomycin binding are indicated. Amino acid residues of protein S12 that were mutated to cysteines and modified with the IAANS fluorophore are shown in magenta. $(C)$ Chemical structure of IAANS. 
located at the tip of the protein loop formed by residues 40-52, forms hydrogen bonds with two hydroxyls of streptomycin (at positions 5 and 6 of ring I). In addition, the $\varepsilon$-amino group of Lys $_{90}$, located in another loop of S12, is only $3 \AA$ away from the $3^{\prime}$-aldehyde oxygen in ring II of streptomycin (residues 86-96) (Carter et al. 2000).

In order to monitor binding of streptomycin to the ribosome, the fluorophore 2-[4'-(iodoacetamido)anilino]naphthalene-6-sulfonic acid (IAANS) (Fig. 1C) was attached at one of three positions of S12: residues 44, 48, or 88, located in loops that approach the antibiotic (Fig. 1B). Initially, mutant versions of protein $\mathrm{S} 12$ were engineered (P44C, L48C, and D88C), which contained single cysteine residues at the corresponding positions (Hickerson et al. 2005; L Lancaster, unpubl.). The mutant proteins were overexpressed, purified, and modified with IAANS at the unique cysteines. $30 \mathrm{~S}$ subunits were assembled in vitro from the $16 \mathrm{~S}$ rRNA and sets of individually purified small subunit proteins where the wild-type S12 was replaced with a fluorescently labeled derivative (Culver and Noller 2000; Hickerson et al. 2005). The reconstituted 30 S subunits were isolated from sucrose gradients and used in the binding studies.

Binding of streptomycin to the fluorescently labeled $30 S$ subunits resulted in quenching of fluorescence in a concentration-dependent manner. Up to $86 \%$ of the fluorescence signal was quenched upon saturation binding of streptomycin to the D88C mutant (Fig. 2C). Quenching of fluorescence observed with the L48C mutant was comparably strong (Fig. 2B). Although streptomycin-dependent quenching with the IAANS-modified P44C mutant was somewhat less pronounced ( $\sim 45 \%$ at saturation), it was
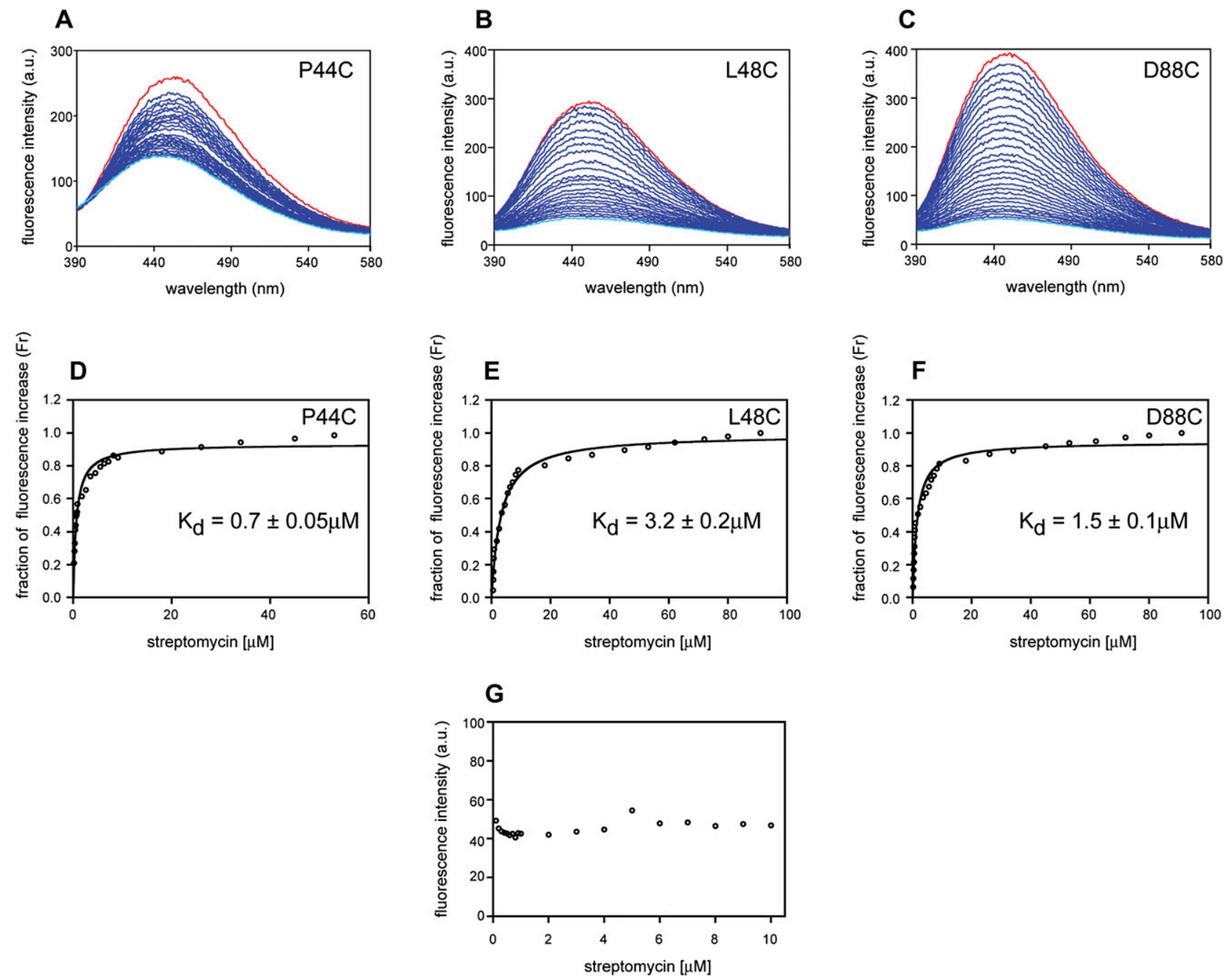

FIGURE 2. Effect of streptomycin binding on fluorescence of 30 S subunits carrying the IAANS fluorophore at positions $44(A, D)$, $48(B, E)$, or 88 $(C, F)$ of protein $S 12$. $(A-C)$ Fluorescence change (arbitrary units [a.u.]) induced by streptomycin binding. (D-F) Plots representing relative fluorescence change (Fr) as a function of antibiotic concentration. $(G)$ Effect of streptomycin on fluorescence of isolated protein S12 carrying the IAANS fluorophore at position 48. 
sufficiently strong for reliable measurements of the drug binding characteristics (Fig. 2A). The fluorescence response was used to generate the binding isotherms (Fig. 2D-F) and to calculate dissociation constants $\left(K_{\mathrm{d}}\right)$, which for different mutants varied in the narrow range of $0.7-3.2 \mu \mathrm{M}$ (Table $1)$. These values are in excellent agreement with the $K_{\mathrm{d}}$ for streptomycin $(0.1-10 \mu \mathrm{M})$ determined using conventional techniques such as equilibrium dialysis or filter binding (Chang and Flaks 1972; Schreiner and Nierhaus 1973; Böck et al. 1979; Grise-Miron and Brakier-Gingras 1982). No effect was observed when the isolated protein S12 IAANS modified at position 48 was incubated with streptomycin (Fig. 2G).

Having established that fluorescently labeled ribosomes can respond to a ligand that binds in the immediate vicinity of the fluorophore, we tested whether binding of a ligand that induces allosteric conformational changes can be detected. The 4,5-substituted deoxystreptamine antibiotics, neomycin and other drugs of this class, bind to the upper part of helix 44 in the small ribosomal subunit (Brodersen et al. 2000; Carter et al. 2000; Ogle et al. 2001). Upon binding, these antibiotics displace two adenine residues, A1492 and A1493, from their resting positions in the RNA double helix. The drug-induced conformation of A1492 and A1493 mimics the orientation these adenines assume during aminoacyl-tRNA selection, when they monitor the RNA minor groove of the codon-anticodon helix (Carter et al. 2000; Wimberly et al. 2000; Ogle et al. 2001). In their flipped-out conformations, the A1492 and A1493 bases invade an unoccupied space in the vicinity of loops $40-52$ and 86-96 of protein S12, and may thus perturb fluorophores attached to amino acid residues positioned in these loops.

We measured binding of neomycin to reconstituted $30 \mathrm{~S}$ subunits carrying the IAANS-modified D88C mutant of S12. Binding of the drug to the small ribosomal subunit led to a concentration-dependent increase in fluorescence, which saturated at $22 \%$ (Fig. 3). The dissociation constant calculated from the resulting binding isotherm corresponded to a $K_{\mathrm{d}}$ value of $0.8 \mu \mathrm{M}$. To the best of our knowledge, this result represents the first direct measurement of the affinity of neomycin for the small ribosomal subunit.

TABLE 1. Dissociation constants $\left(K_{\mathrm{d}}\right)$ for streptomycin and neomycin complexes with fluorescently labeled $30 S$ subunits.

\begin{tabular}{lcc}
\hline Antibiotic & $\begin{array}{c}\text { IAANS-modified } \\
\text { position in S12 }\end{array}$ & $\begin{array}{c}K_{\mathrm{d}} \\
(\mu \mathrm{M})\end{array}$ \\
\hline Streptomycin & P44C & $0.70 \pm 0.05$ \\
& L48C & $3.2 \pm 0.2$ \\
D88C & $1.5 \pm 0.1$ \\
Neomycin & D88C & $0.8 \pm 0.1$ \\
\hline
\end{tabular}

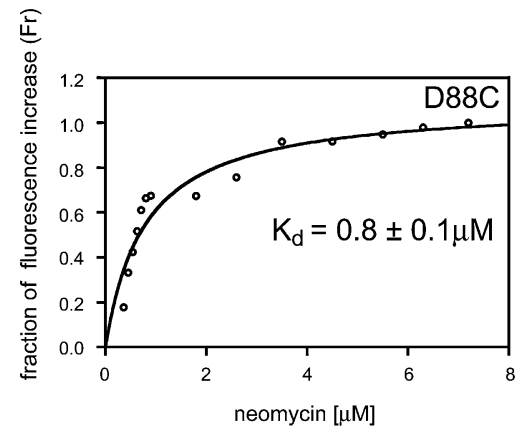

FIGURE 3. Binding of neomycin to 30 S subunits modified by IAANS at position 88 of protein S12. The plot represents the relative fluorescence change (Fr) as a function of neomycin concentration.

Finally, we confirmed that binding of an antibiotic at a position remote from the fluorophore fails to systematically affect the fluorescent properties of the IAANS-modified small subunits. For this experiment, we used spectinomycin, an aminocyclitol drug that binds to helix 34 of $16 \mathrm{~S}$ rRNA, more than $30 \AA$ from the positions of the fluorophores covalently attached to protein S12 (Borovinskaya et al. 2007). Although binding of spectinomycin to $30 \mathrm{~S}$ subunits labeled using the D88C mutant of S12 caused some detectable fluctuations in fluorescence, no regular concentrationdependent changes were observed (data not shown), consistent with the expectation that S12-bound fluorophores report on changes in their immediate environment.

\section{DISCUSSION}

Fluorescence spectroscopy has been widely used to study binding of fluorophore-modified high-molecular-weight ligands (e.g., tRNAs, translation factors, or mRNA) to the ribosome (Rodnina and Wintermeyer 1992; Rodnina et al. 1996; Studer et al. 2003; Blanchard et al. 2004; Ermolenko et al. 2007; Wang et al. 2007; Pan et al. 2009). This approach, however, is less applicable to the study of smallmolecule ligands, such as antibiotics. When the size of a fluorophore approaches or even exceeds that of the antibiotic, its binding properties can be dramatically altered. To overcome this obstacle, we developed a novel approach, in which an environment-sensitive fluorescent probe is attached not to the ligand, but to the ribosome. The utility of this approach was tested by incorporating fluorescently modified versions of protein S12 into the small ribosomal subunit and monitoring fluorescence changes in response to binding of the antibiotics streptomycin, neomycin, and spectinomycin, whose binding sites are located at various distances from the labeled positions of S12. Our results show that appropriately placed fluorophores are able to report on the interactions of small antibiotic molecules with the macromolecular giant of the ribosome.

The labeled amino acid residues 44,48 , and 88 of protein S12 are located at a distance of $4 \AA, 18 \AA$, and $10 \AA$, 
respectively, from the streptomycin molecule complexed with the Escherichia coli 30S subunit (Carter et al. 2000). The fairly large IAANS fluorophore attached at the positions most proximal to the antibiotic binding site may come into direct contact with the antibiotic and could thus potentially influence drug binding. In agreement with this possibility, we noticed a progressive, fivefold increase in affinity when IAANS is moved from the most distant location (Fig. 2B,E, position 48) to the most proximal position to the drug (Fig. 2A,D, position 44). This tendency suggests that direct interaction of streptomycin with the IAANS moiety may contribute to some extent to drug binding. Thus, for accurate measurements of binding parameters, the fluorophore should be placed at a sufficient distance from the antibiotic binding site to avoid direct interaction with the drug. Nevertheless, the relatively small variation in the $K_{\mathrm{d}}$ for streptomycin obtained with different fluorescently modified S12 mutants and the close agreement of the affinity values obtained by spectrofluorometry to those obtained by more traditional techniques attest to the fact that our approach can provide reliable binding parameters.

Our experiments with neomycin, which binds some distance from the site of the IAANS label in the ribosome, illustrate an additional advantage of this method: As long as ligand binding generates an allosteric conformational change that is transmitted to the site of placement of the fluorescent label, the antibiotic binding parameters can be measured. In the case of neomycin, two types of allosteric effects could in principle bring about the observed fluorescence response. The simplest scenario is that neomycindependent displacement of the two adenine residues, A1492 and A1493, from helix 44 into their flipped-out conformations could be sufficient to account for alterations in the fluorescence properties of IAANS attached at position 88 of S12 (Fig. 2C,F). Another possibility is that a more global change of the subunit structure induced by neomycin is responsible for the observed effects. Indeed, in the D88C S12 mutant the fluorophore is located in a region of the small subunit that has been implicated in global reorientation of the subunit major domains in response to binding of various ligands. Crystallographic studies have shown that the precise constellation of rRNA elements in this site, as well as the conformations of several residues of protein $\mathrm{S} 12$, are affected by an open $\Leftrightarrow$ closed transition of the small ribosomal subunit induced by binding of cognate aminoacyl-tRNA to the ribosomal A site (Yusupov et al. 2001; Ogle et al. 2002). Furthermore, there is strong biochemical evidence for structural communication between the sites of binding of aminoglycosides in helix 44 and the site of streptomycin binding in the vicinity of helix 18 and protein S12. Thus, binding of streptomycin to the $30 \mathrm{~S}$ subunit is enhanced by the presence of neomycin or paromomycin, and, reciprocally, binding of paromomycin to the ribosome is stimulated in the presence of streptomycin (Chang and Flaks 1972; Lando et al. 1976; Grise-Miron and Brakier-Gingras 1982). The 16S rRNA residue C525 in helix 18 becomes more accessible to dimethyl sulfate modification upon binding of neomycin and related aminoglycosides to helix 44 (Moazed and Noller 1987). All these effects likely reflect an antibioticinduced global conformational change in the small ribosomal subunit, which could be responsible for the observed change in the fluorescent properties of the IAANS fluorophore.

The $K_{\mathrm{d}}$ for neomycin determined in our experiments $(0.8 \mu \mathrm{M})$ represents the first direct measurement of the affinity of the drug for the $30 \mathrm{~S}$ subunit. Until now, there have been only a few attempts to obtain quantitative parameters for the binding of aminoglycosides to the $30 \mathrm{~S}$ subunit. In two studies, equilibrium dialysis was employed to analyze binding of radiolabeled kanamycin $\left(K_{\mathrm{d}}=1.8\right.$ $\mu \mathrm{M})$ and tobramycin $\left(K_{\mathrm{d}}=1 \mu \mathrm{M}\right)$ (Misumi et al. 1978; Le Goffic et al. 1979). In another work, labor-intensive RNA footprinting was used to extract semiquantitative parameters for paromomycin binding $\left(K_{\mathrm{d}}=0.1 \mu \mathrm{M}\right)$ (Sharma et al. 2007). The vast majority of the information on aminoglycoside interactions with their respective RNA targets has come from the analysis of drug binding to model RNA substrates (for example, Recht et al. 1996; Vicens and Westhof 2001; Llano-Sotelo et al. 2002; Vicens and Westhof 2002; Pilch et al. 2003; Francois et al. 2005). Although the studies of drug-RNA interactions based on the use of short RNA constructs were illuminating (Recht et al. 1996; Lynch et al. 2003), the crystal structures of ribosomal subunit complexes show that more dramatic conformational changes are observed in the rRNA of the intact 30 S subunit upon aminoglycoside binding compared to those of the simplified substrates (Carter et al. 2000; Lynch et al. 2003). Furthermore, only studies involving the entire ribosomal subunit are capable of revealing the effects of global conformational changes and of other ribosomal ligands on antibiotic binding, which underscores the utility of the technique described here.

The method we propose, although not free from its own intrinsic limitations, offers interesting potential applications that are not readily amenable to previous approaches. Admittedly, preparation of site-specifically fluorescently labeled ribosomes is a fairly demanding procedure. However, once the labeled subunits are in hand, a large range of antibiotics can be rapidly tested for binding to sites in reasonable proximity to the site of fluorophore placement. Furthermore, this method can be applied to testing the binding of novel antibiotics and lead compounds, whose sites of interaction with the ribosome are not well characterized. As an example, we have recently applied this technique to validate binding of short peptides capable of inhibiting ribosome functions (B Llano-Sotelo, D Klepacki, AS Mankin, unpubl.). An important advantage of this technique, which we have not yet explored but whose 
general utility has been demonstrated in similar studies, is that time-resolved fluorometry offers an easy way to analyze the kinetics of antibiotic binding to the ribosome. Finally, this approach can be used in high-throughput assays for identification of small ligands capable of site-specific interactions with the ribosome, and thus can facilitate drug discovery.

\section{MATERIALS AND METHODS}

\section{Reagents}

Tris-(2-carboxyethyl)phosphine, hydrochloride (TCEP) (Catalog No. 93284), streptomycin (Catalog No. S-9137), and neomycin sulfate (Catalog No. N-1876) were obtained from Sigma. Nikkol was obtained from Calbiochem (Catalog No. 205528). IAANS was purchased from Invitrogen (Catalog No. I-7). All other chemicals were from Fisher Scientific unless indicated otherwise.

\section{Buffers}

The following buffer solutions were used:

Buffer A: $80 \mathrm{mM}$ Hepes-KOH (pH 7.6), $20 \mathrm{mM} \mathrm{MgCl}_{2}, 6 \mathrm{mM}$ $\beta$-mercaptoethanol;

Buffer B: $80 \mathrm{mM}$ Hepes-KOH (pH 7.6), $20 \mathrm{mM} \mathrm{MgCl}, 1 \mathrm{M} \mathrm{KCl}$, $6 \mathrm{mM} \beta$-mercaptoethanol;

Buffer C: 80 mM Hepes-KOH (pH 7.5), $1 \mathrm{M} \mathrm{KCl,} 1 \mathrm{mM}$ TCEP;

Buffer D: $10 \mathrm{mM}$ Tris-HCl (pH 6.3), $6 \mathrm{M}$ urea, $1 \mathrm{M} \mathrm{KCl}, 0.01 \%$ Nikkol, $6 \mathrm{mM} \beta$-mercaptoethanol;

Buffer E: $10 \mathrm{mM}$ Tris-HCl (pH 6.3), $6 \mathrm{M}$ urea, $10 \mathrm{mM} \mathrm{KCl,} \mathrm{0.01 \%}$ Nikkol, $6 \mathrm{mM} \beta$-mercaptoethanol;

Buffer F: $10 \mathrm{mM}$ Tris-HCl (pH 6.3), $6 \mathrm{M}$ urea, 0.01\% (v/v) Nikkol; and

Buffer G: $50 \mathrm{mM}$ Hepes-KOH (pH 7.3), $20 \mathrm{mM} \mathrm{MgCl}_{2}, 100 \mathrm{mM}$ $\mathrm{NH}_{4} \mathrm{Cl}, 6 \mathrm{mM} \beta$-mercaptoethanol.

\section{Ribosomal RNA and proteins}

$16 \mathrm{~S}$ rRNA was obtained by phenol extraction of $30 \mathrm{~S}$ subunits as described previously (Moazed et al. 1986), and stored in buffer A at a concentration of $16.9 \mu \mathrm{M}$. Wild-type ribosomal proteins were overexpressed in E. coli strain BLR(DE3), and purified by FPLC chromatography as described previously (Hickerson et al. 2005). Purified proteins were dialyzed against buffer B, flash frozen in liquid nitrogen, and stored at $-80^{\circ} \mathrm{C}$.

\section{Incorporation of fluorescent label in protein $\mathrm{S} 12$}

The plasmid carrying the E. coli gene rpsL encoding ribosomal protein S12 was constructed by PCR-amplifying rpsL from the chromosome of E. coli MRE600 and cloning it into pET24b (Hickerson et al. 2005; L Lancaster, unpubl.). Four cysteine residues of wild-type S12 were mutated to serine (position 26), alanine (positions 33 and 52), and threonine (position 103) (Kunkel et al. 1991). Single-cysteine residues were then introduced at positions 44,48 , or 88 of the protein as described previously (Hickerson et al. 2005). Single-cysteine mutant S12 proteins were purified by FPLC, dialyzed against buffer C, and stored at $-80^{\circ} \mathrm{C}$. In order to conjugate the fluorophore with the cysteine residues of the S12 mutants, the protein (at a concentration of $40 \mu \mathrm{M}$ ) was pre-incubated in $1.7 \mathrm{~mL}$ of buffer $\mathrm{C}$ at $20^{\circ} \mathrm{C}$ for $20 \mathrm{~min}$. IAANS (dissolved in $\mathrm{N}, \mathrm{N}$-dimethylformamide at a concentration of 20 $\mathrm{mM}$ ) was added to a final concentration of $320 \mu \mathrm{M}$, and the reaction was incubated in the dark at $20^{\circ} \mathrm{C}$ for $2 \mathrm{~h}$. At the end of the incubation, the reaction was quenched by addition of $5 \mu \mathrm{L}$ of $\beta$-mercaptoethanol.

The fluorescently labeled S12 proteins were purified by ionexchange chromatography as described previously (Hickerson et al. 2005) with minor modifications. A minicolumn (Promega, Catalog No. A721B) was packed with $1 \mathrm{~mL}$ of SP Sepharose Fast Flow resin (Amersham Biosciences, Catalog No. 17-0729-10). A $0.8 \mu \mathrm{m}$ pore-size cellulose acetate filter (Corning, Catalog No. 431221) was attached to the top of the column, and the resin was equilibrated by passing $3 \mathrm{~mL}$ of buffer $\mathrm{D}$, followed by $10 \mathrm{~mL}$ of buffer E. The modified protein $(1.7 \mathrm{~mL})$ was diluted to $40 \mathrm{~mL}$ with buffer $\mathrm{F}$ and loaded onto the column. After washing the column with $10 \mathrm{~mL}$ of buffer E, the protein was eluted with $1 \mathrm{~mL}$ of buffer $\mathrm{D}$. The eluted protein was dialyzed over $4 \mathrm{~h}$ against three changes of $300 \mathrm{~mL}$ of buffer B. The purified, fluorescently labeled protein was aliquoted, flash frozen in liquid nitrogen, and stored at $-80^{\circ} \mathrm{C}$. The protein was analyzed by gel electrophoresis in a $15 \%$ SDS-PAGE (Schagger and von Jagow 1987). The concentration of the fluorescently labeled S12 proteins was determined using the reported extinction coefficient for IAANS $\left(27,000 \mathrm{M}^{-1}\right.$ $\mathrm{cm}^{-1}$ ) (Invitrogen).

\section{Reconstitution of $30 \mathrm{~S}$ ribosomal subunits}

Reconstitution of the small ribosomal subunit using purified ribosomal proteins was performed by addition of a sevenfold molar excess of primary, secondary, and tertiary binding proteins to $16 \mathrm{~S}$ rRNA, in a stepwise fashion, as previously described (Culver and Noller 2000; Hickerson et al. 2005). Subunits were purified by sucrose gradient centrifugation.

\section{Titration of $30 \mathrm{~S}$ subunits with antibiotics}

The fluorescently labeled $30 \mathrm{~S}$ subunits were diluted to $100 \mathrm{nM}$ in $440 \mu \mathrm{L}$ of buffer $\mathrm{G}$, incubated at $42^{\circ} \mathrm{C}$ for $10 \mathrm{~min}$, placed on ice for $20 \mathrm{~min}$, and then transferred to a quartz cuvette (Varian, Catalog No. 6610021500). Prior to addition of ligands, the cuvette was incubated at $37^{\circ} \mathrm{C}$ for $2 \mathrm{~min}$ in the temperature-controlled cuvette holder of the Varian Cary Eclipse Fluorescence Spectrophotometer. An initial emission spectrum was obtained with an excitation wavelength of $328 \mathrm{~nm}$ over the range of 350-600 nm. Aliquots of antibiotics prepared in $50 \mathrm{mM}$ Hepes- $\mathrm{KOH}(\mathrm{pH} 7.3$ ) were added sequentially in volumes of $1 \mu \mathrm{L}$ to obtain the desired ligand concentrations. After addition of each aliquot, the solution in the cuvette was stirred with a disposable polystyrene cuvette sitrrer (Fisher Scientific, Catalog No. 14-386-22), and fluorescence emission spectra were taken after 2 min of incubation at $37^{\circ} \mathrm{C}$.

$K_{\mathrm{d}}$ values were calculated using the equation $\mathrm{Fr}=\left(F_{0}-F_{i}\right) /\left(F_{0}-\right.$ $F_{f}$ ), where $\mathrm{Fr}$ is the fraction of maximal fluorescence change, $F_{0}$ is fluorescence in the absence of antibiotic, $F_{i}$ is fluorescence at any given concentration of the antibiotic, and $F_{f}$ is fluorescence at the final (saturating) concentration of antibiotic. The data were fitted into the hyperbolic one-site binding equation using GraphPad Prism software (version 4.0c) (GraphPad Software). 


\section{Structure modeling and figure preparation}

In order to represent streptomycin, neomycin, and spectinomycin in the structure of $30 \mathrm{~S}$ subunits, the Protein Data Bank (PDB) coordinates of the complex of neomycin bound to the E. coli ribosome (2QAL) were taken as an anchor model. The coordinates of 16S rRNA residues 923-1390 of the complex of spectinomycin bound to the E. coli ribosome (2QOU) were aligned to those of the corresponding $16 \mathrm{~S}$ residues of the $2 \mathrm{QAL}$ structure. Finally, to place streptomycin in the E. coli ribosome, the structure of the Thermus thermophilus 30S subunit complexed with streptomycin was aligned with the 2QAL structure using the same set of 16S rRNA residues (positions 923-1390). The figures were prepared using PyMol (DeLano Scientific LLC).

\section{ACKNOWLEDGMENTS}

We thank Dorota Klepacki for her help with some experiments. This work was supported by a grant from the National Institutes of Health U19 AI56575 (to A.S.M.) and by grants from the NIH and NSF (to H.F.N.)

Received April 8, 2009; accepted May 14, 2009.

\section{REFERENCES}

Ban N, Nissen P, Hansen J, Moore PB, Steitz TA. 2000. The complete atomic structure of the large ribosomal subunit at $2.4 \AA$ resolution. Science 289: 905-920.

Belova L, Tenson T, Xiong L, McNicholas PM, Mankin AS. 2001. A novel site of antibiotic action in the ribosome: Interaction of evernimicin with the large ribosomal subunit. Proc Natl Acad Sci 98: $3726-3731$.

Blanchard SC, Kim HD, Gonzalez RL Jr, Puglisi JD, Chu S. 2004. tRNA dynamics on the ribosome during translation. Proc Natl Acad Sci 101: 12893-12898.

Böck A, Petzet A, Piepersberg W. 1979. Ribosomal ambiguity (ram) mutations facilitate dihydrostreptomycin binding to ribosomes. FEBS Lett 104: 317-321.

Borovinskaya MA, Shoji S, Holton JM, Fredrick K, Cate JH. 2007. A steric block in translation caused by the antibiotic spectinomycin. ACS Chem Biol 2: 545-552.

Böttger EC. 2007. Antimicrobial agents targeting the ribosome: The issue of selectivity and toxicity-lessons to be learned. Cell Mol Life Sci 64: 791-795.

Brandi L, Dresios J, Gualerzi CO. 2008a. Assays for the identification of inhibitors targeting specific translational steps. Methods Mol Med 142: 87-105.

Brandi L, Fabbretti A, Pon CL, Dahlberg AE, Gualerzi CO. 2008b. Initiation of protein synthesis: A target for antimicrobials. Expert Opin Ther Targets 12: 519-534.

Brandt-Rauf P, Vince R, LeMahieu R, Pestka S. 1978. Fluorescent assay for estimating the binding of erythromycin derivatives to ribosomes. Antimicrob Agents Chemother 14: 88-94.

Brodersen DE, Clemons WM Jr, Carter AP, Morgan-Warren RJ, Wimberly BT, Ramakrishnan V. 2000. The structural basis for the action of the antibiotics tetracycline, pactamycin, and hygromycin B on the 30S ribosomal subunit. Cell 103: 1143-1154.

Carter AP, Clemons WM, Brodersen DE, Morgan-Warren RJ, Wimberly BT, Ramakrishnan V. 2000. Functional insights from the structure of the $30 \mathrm{~S}$ ribosomal subunit and its interactions with antibiotics. Nature 407: 340-348.

Chang FN, Flaks JG. 1972. Binding of dihydrostreptomycin to Escherichia coli ribosomes: Characteristics and equilibrium of the reaction. Antimicrob Agents Chemother 2: 294-307.
Culver GM, Noller HF. 2000. In vitro reconstitution of 30 S ribosomal subunits using complete set of recombinant proteins. Methods Enzymol 318: 446-460.

Ermolenko DN, Majumdar ZK, Hickerson RP, Spiegel PC, Clegg RM, Noller HF. 2007. Observation of intersubunit movement of the ribosome in solution using FRET. J Mol Biol 370: 530-540.

Francois B, Russell RJ, Murray JB, Aboul-ela F, Masquida B, Vicens Q, Westhof E. 2005. Crystal structures of complexes between aminoglycosides and decoding A site oligonucleotides: Role of the number of rings and positive charges in the specific binding leading to miscoding. Nucleic Acids Res 33: 5677-5690.

Green R, Noller HF. 1997. Ribosomes and translation. Annu Rev Biochem 66: 679-716.

Grise-Miron L, Brakier-Gingras L. 1982. Effect of neomycin and protein $\mathrm{S} 1$ on the binding of streptomycin to the ribosome. Eur J Biochem 123: 643-646.

Hall J, Davis JP, Cantor CR. 1977. Interaction of a fluorescent streptomycin derivative with Escherichia coli ribosomes. Arch Biochem Biophys 179: 121-130.

Hickerson R, Majumdar ZK, Baucom A, Clegg RM, Noller HF. 2005. Measurement of internal movements within the $30 \mathrm{~S}$ ribosomal subunit using Forster resonance energy transfer. J Mol Biol 354: 459-472.

Kunkel TA, Bebenek K, McClary J. 1991. Efficient site-directed mutagenesis using uracil-containing DNA. Methods Enzymol 204: $125-139$.

Lando D, Cousin MA, Ojasoo T, Raymond JP. 1976. Paromomycin and dihydrostreptomycin binding to Escherichia coli ribosomes. Eur J Biochem 66: 597-606.

Le Goffic F, Capmau ML, Tangy F, Baillarge M. 1979. Mechanism of action of aminoglycoside antibiotics. Binding studies of tobramycin and its $6^{\prime}-N$-acetyl derivative to the bacterial ribosome and its subunits. Eur J Biochem 102: 73-81.

Leach KL, Swaney SM, Colca JR, McDonald WG, Blinn JR, Thomasco LM, Gadwood RC, Shinabarger D, Xiong L, Mankin AS. 2007. The site of action of oxazolidinone antibiotics in living bacteria and in human mitochondria. Mol Cell 26: 393402.

Lee D, Walsh JD, Yu P, Markus MA, Choli-Papadopoulou T, Schwieters CD, Krueger S, Draper DE, Wang YX. 2007. The structure of free L11 and functional dynamics of L11 in free, L11rRNA(58 nt) binary, and L11-rRNA(58 nt)-thiostrepton ternary complexes. J Mol Biol 367: 1007-1022.

Llano-Sotelo B, Azucena EF Jr, Kotra LP, Mobashery S, Chow CS. 2002. Aminoglycosides modified by resistance enzymes display diminished binding to the bacterial ribosomal aminoacyl-tRNA site. Chem Biol 9: 455-463.

Lynch SR, Gonzalez RL, Puglisi JD. 2003. Comparison of X-ray crystal structure of the $30 \mathrm{~S}$ subunit-antibiotic complex with NMR structure of decoding site oligonucleotide-paromomycin complex. Structure 11: 43-53.

Maguire BA, Beniaminov AD, Ramu H, Mankin AS, Zimmermann RA. 2005. A protein component at the heart of an RNA machine: The importance of protein 127 for the function of the bacterial ribosome. Mol Cell 20: 427-435.

McNicholas PM, Najarian DJ, Mann PA, Hesk D, Hare RS, Shaw KJ, Black TA. 2000. Evernimicin binds exclusively to the 50S ribosomal subunit and inhibits translation in cell-free systems derived from both gram-positive and gram-negative bacteria. Antimicrob Agents Chemother 44: 1121-1126.

Misumi M, Nishimura T, Komai T, Tanaka N. 1978. Interaction of kanamycin and related antibiotics with the large subunit of ribosomes and the inhibition of translocation. Biochem Biophys Res Commun 84: 358-365.

Moazed D, Noller HF. 1987. Interaction of antibiotics with functional sites in 16S ribosomal RNA. Nature 327: 389-394.

Moazed D, Stern S, Noller HF. 1986. Rapid chemical probing of conformation in $16 \mathrm{~S}$ ribosomal RNA and $30 \mathrm{~S}$ ribosomal subunits using primer extension. J Mol Biol 187: 399-416. 
Moore PB, Steitz TA. 2003. The structural basis of large ribosomal subunit function. Annu Rev Biochem 72: 813-850.

Ogle JM, Brodersen DE, Clemons WM Jr, Tarry MJ, Carter AP, Ramakrishnan V. 2001. Recognition of cognate transfer RNA by the 30S ribosomal subunit. Science 292: 897-902.

Ogle JM, Murphy FV, Tarry MJ, Ramakrishnan V. 2002. Selection of tRNA by the ribosome requires a transition from an open to a closed form. Cell 111: 721-732.

Ogle JM, Carter AP, Ramakrishnan V. 2003. Insights into the decoding mechanism from recent ribosome structures. Trends Biochem Sci 28: 259-266.

Pan D, Qin H, Cooperman BS. 2009. Synthesis and functional activity of tRNAs labeled with fluorescent hydrazides in the D-loop. RNA 15: $346-354$.

Pilch DS, Kaul M, Barbieri CM, Kerrigan JE. 2003. Thermodynamics of aminoglycoside-rRNA recognition. Biopolymers 70: 58-79.

Recht MI, Fourmy D, Blanchard SC, Dahlquist KD, Puglisi JD. 1996. RNA sequence determinants for aminoglycoside binding to an Asite rRNA model oligonucleotide. J Mol Biol 262: 421-436.

Rodnina MV, Pape T, Fricke R, Kuhn L, Wintermeyer W. 1996. Initial binding of the elongation factor Tu•GTP•aminoacyl-tRNA complex preceding codon recognition on the ribosome. J Biol Chem 271: 646-652.

Rodnina MV, Wintermeyer W. 1992. Two tRNA-binding sites in addition to $\mathrm{A}$ and $\mathrm{P}$ sites on eukaryotic ribosomes. J Mol Biol 228: 450-459.

Schagger H, von Jagow G. 1987. Tricine-sodium dodecyl sulfatepolyacrylamide gel electrophoresis for the separation of proteins in the range from 1 to $100 \mathrm{kDa}$. Anal Biochem 166: 368-379.

Schluenzen F, Tocilj A, Zarivach R, Harms J, Gluehmann M, Janell D, Bashan A, Bartels H, Agmon I, Franceschi F, et al. 2000. Structure of functionally activated small ribosomal subunit at $3.3 \AA$ resolution. Cell 102: 615-623.

Schreiner G, Nierhaus KH. 1973. Protein involved in the binding of dihydrostreptomycin to ribosomes of Escherichia coli. J Mol Biol 81: 71-82.

Schuwirth BS, Day JM, Hau CW, Janssen GR, Dahlberg AE, Cate JH, Vila-Sanjurjo A. 2006. Structural analysis of kasugamycin inhibition of translation. Nat Struct Mol Biol 13: 879-886.

Sharma D, Cukras AR, Rogers EJ, Southworth DR, Green R. 2007. Mutational analysis of S12 protein and implications for the accuracy of decoding by the ribosome. J Mol Biol 374: 10651076.
Studer SM, Feinberg JS, Joseph S. 2003. Rapid kinetic analysis of EFG-dependent mRNA translocation in the ribosome. J Mol Biol 327: 369-381.

Tejedor F, Amils R, Ballesta JP. 1985. Photoaffinity labeling of the pactamycin binding site on eubacterial ribosomes. Biochemistry 24: 3667-3672.

Tejedor F, Ballesta JP. 1985. Ribosome structure: Binding site of macrolides studied by photoaffinity labeling. Biochemistry 24: 467472.

Vicens Q, Westhof E. 2001. Crystal structure of paromomycin docked into the eubacterial ribosomal decoding A site. Structure 9: 647658.

Vicens Q, Westhof E. 2002. Crystal structure of a complex between the aminoglycoside tobramycin and an oligonucleotide containing the ribosomal decoding A site. Chem Biol 9: 747-755.

Wang Y, Qin H, Kudaravalli RD, Kirillov SV, Dempsey GT, Pan D, Cooperman BS, Goldman YE. 2007. Single-molecule structural dynamics of EF-G-ribosome interaction during translocation. Biochemistry 46: 10767-10775.

Wenzel RP, Edmond MB. 2000. Managing antibiotic resistance. $N$ Engl J Med 343: 1961-1963.

Wilson DN, Schluenzen F, Harms JM, Starosta AL, Connell SR, Fucini P. 2008. The oxazolidinone antibiotics perturb the ribosomal peptidyl-transferase center and effect tRNA positioning. Proc Natl Acad Sci 105: 13,339-13,344.

Wimberly BT, Brodersen DE, Clemons WM Jr, Morgan-Warren RJ, Carter AP, Vonrhein C, Hartsch T, Ramakrishnan V. 2000. Structure of the 30S ribosomal subunit. Nature 407: 327-339.

Yan K, Hunt E, Berge J, May E, Copeland RA, Gontarek RR. 2005. Fluorescence polarization method to characterize macrolideribosome interactions. Antimicrob Agents Chemother 49: 3367-3372.

Yassin A, Fredrick K, Mankin AS. 2005. Deleterious mutations in small subunit ribosomal RNA identify functional sites and potential targets for antibiotics. Proc Natl Acad Sci 102: 16620-16625.

Yassin A, Mankin AS. 2007. Potential new antibiotic sites in the ribosome revealed by deleterious mutations in RNA of the large ribosomal subunit. J Biol Chem 282: 24329-24342.

Yonath A. 2005. Antibiotics targeting ribosomes: Resistance, selectivity, synergism, and cellular regulation. Annu Rev Biochem 74: 649679.

Yusupov MM, Yusupova GZ, Baucom A, Lieberman K, Earnest TN, Cate JH, Noller HF. 2001. Crystal structure of the ribosome at 5.5 A resolution. Science 292: 883-896. 

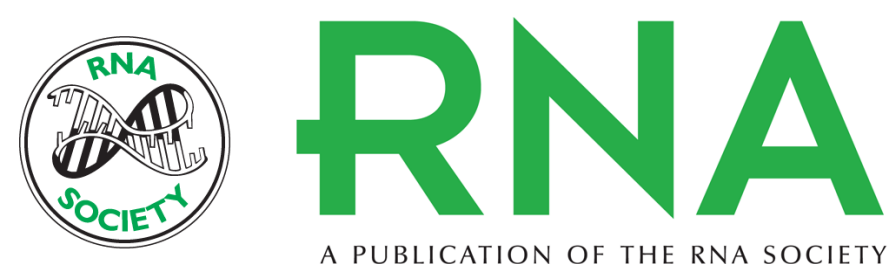

A PUBLICATION OF THE RNA SOCIETY

\section{Fluorescently labeled ribosomes as a tool for analyzing antibiotic binding}

Beatriz Llano-Sotelo, Robyn P. Hickerson, Laura Lancaster, et al.

RNA 2009 15: 1597-1604 originally published online June 24, 2009

Access the most recent version at doi:10.1261/rna.1681609

$\begin{array}{ll}\text { References } & \begin{array}{l}\text { This article cites } 59 \text { articles, } 14 \text { of which can be accessed free at: } \\ \text { http://rnajournal.cshlp.org/content/15/8/1597.full.html\#ref-list-1 }\end{array}\end{array}$

License

Email Alerting Receive free email alerts when new articles cite this article - sign up in the box at the Service top right corner of the article or click here. 